\title{
Fusarium incarnatum
}

National Cancer Institute

\section{Source}

National Cancer Institute. Fusarium incarnatum. NCI Thesaurus. Code C127712.

A fung al plant pathogen in the phylum Ascomycota. 